\title{
DUALISME KEWENANGAN MENGADILI PERKARA ANAK SEBAGAI PELAKU KEJAHATAN PELECEHAN SEKSUAL DI KOTA LANGSA-ACEH
}

\author{
Liza Agnesta Krisna, Rini Fitriani \\ Fakultas Hukum Universitas Samudra-Meurandeh-Langsa-Aceh \\ Email: agnes_krisna@unsam.ac.id,rinifitriani@unsam.ac.id
}

\begin{abstract}
Abstrak
Tujuan penelitian ini adalah untuk mengetahui mengapa terjadi dualisme kewenangan mengadili perkara anak sebagai pelaku kejahatan pelecehan seksual di Kota LangsaAceh. Penelitian ini digunakan jenis penelitian deskriptif analitis, dengan metode pendekatan yuridis empiris yaitu metode meneliti hak kewenangan mengadili perkara anak di Kota Langsa-Aceh dalam penerapan kenyataan hukumnya terjadi dualisme kewenangan mengadili perkara anak sebagai pelaku kejahatan pelecehan seksual di Kota Langsa. Kesimpulan yang dihasilkan adalah dualisme terjadi akibat dua ketentuan peraturan perundang-undangan yang digunakan untuk penegakan hukum perkara anak sebagai pelaku kejahatan pelecehan seksual terhadap anak yaitu Undang-Undang Nomor 35 Tahun 2014 tentang Perubahan Undang-Undang Nomor 23 Tahun 2002 tentang Perlindungan Anak, kewenangan mengadili ada pada Pengadilan Negeri sedangkan Qanun Nomor 6 Tahun 2014 tentang Hukum Jinayat, kewenangan mengadili ada pada Mahkamah Syar'iyah. Penanggulangan yang harus dilakukan oleh Mahkamah Syar'iyah adalah melengkapi sarana dan prasarana sistem peradilan anak yang memadai.
\end{abstract}

\section{Kata kunci: Kewenangan Mengadili, Anak, Kejahatan Pelecehan Seksual}

\begin{abstract}
The purpose of this research is to find out why dualism has the authority to prosecute children cases as perpetrators of sexual harassment in the City of Langsa-Aceh. This study used a descriptive analytical research type, with an empirical juridical approach, that is the method of examining the right of authority to prosecute child cases in Langsa-Aceh City in the application of the legal reality of dualism authority to prosecute child cases as perpetrators of sexual harassment in Langsa City. The conclusion produced is dualism due to the two provisions of the legislation used for law enforcement of child cases as perpetrators of child sexual abuse, namely Law Number 35 of 2014 concerning Amendment to Law Number 23 of 2002 concerning Child Protection, the authority to adjudicate is in the District Court while Qanun Number 6 of 2014 concerning Jinayat's Law, the authority to adjudicate is with the Syar'iyah Court.The response that must be done by the Syar'iyah Court is to provide adequate facilities and infrastructure for the juvenile justice system.
\end{abstract}

Keywords: Kewenangan Mengadili, Anak, Kejahatan Pelecehan Seksual 


\section{A. PENDAHULUAN}

\section{Latar Belakang}

Aceh merupakan salah satu provinsi di Indonesia yang mendapatkan kebijakan penyerahan otonomi khusus melalui Undang-Undang Nomor 44 Tahun 1999 tentang Penyelenggaraan Keistimewaan Provinsi Daerah Istimewa Aceh dan Undang-Undang Nomor 18 Tahun 2001 tentang Otonomi Khusus Bagi Provinsi Daerah Istimewa Aceh. Sejarah Panjang tentang konflik bersenjata antara Gerakan Aceh Merdeka (GAM) yang dipimpin oleh Tengku Muhammad Hasan Tiro terhadap Republik Indonesia sejak tahun 1976, melatarbelakangi penerapan syari'at Islam saat ini di Aceh. Penerapan syari'at Islam dilaksanakan setelah kesepakatan damai tercapai antara Republik Indonesia dengan Aceh yang bernama Memorandum of Understanding (MoU) Helsinki. MoU Helsinkiditandatangani di Helsinki, Finlandia pada tanggal 15 Agustus 2005.

Pemerintah Republik Indonesia dan Gerakan Aceh Merdeka (GAM) menegaskan komitmen mereka untuk penyelesaian konflik Aceh secara damai, menyeluruh, berkelanjutan dan bermartabat bagi semua. Para pihak bertekad untuk menciptakan kondisi sehingga pemerintahan rakyat Aceh dapat diwujudkan melalui suatu proses yang demokratis dan adil dalam negara kesatuan dan konstitusi Republik Indonesia. Para pihak sangat yakin bahwa hanya dengan penyelesaian damai atas konflik tersebut yang akan memungkinkan pembangunan kembali Aceh pasca Tsunami tanggal 26 Desember 2004 dapat mencapai kemajuan dan keberhasilan. Para pihak yang terlibat dalam konflik bertekad untuk membangun rasa saling percaya. ${ }^{1}$

Salah satu point dalam MoU Helsinki adalah lahirnya Undang-Undang Nomor 11 Tahun 2006 tentang Pemerintah Aceh sekaligus menggantikan Undang-Undang Nomor 18 Tahun 2001. Undang-Undang ini lahir atas pertimbangan bahwa sistem pemerintahan Negara Kesatuan Republik Indonesia menurut Undang-Undang Dasar Negara Kesatuan Republik Indonesia Tahun 1945 mengakui dan menghormati satuansatuan pemerintah daerah yang bersifat khusus atau bersifat istimewa yang diatur dengan Undang-Undang Ini. ${ }^{2}$

Urusan wajib yang menjadi kewenangan pemerintahan Aceh dalam pelaksanaan keistimewaan Aceh diantaranya meliputi penyelenggaraan kehidupan beragama dalam

\footnotetext{
1 Memorandum of Understanding between the Government of the Republic of Indonesia and the Free Aceh Movement

2 Undang-Undang Nomor 11 Tahun 2006 tentang Pemerintahan Aceh
} 
bentuk pelaksanaan syari'at Islam bagi pemeluknya di Aceh dengan tetap menjaga kerukunan hidup antarumat beragama. ${ }^{3}$ Ketentuan pelaksanaan undang-undang tersebut yang menyangkut dengan kewenangan pemerintahan Aceh ditetapkan dengan qanun.

Kemudian Pada tanggal 22 Oktober 2014, pemerintah Aceh mengesahkan Qanun Nomor 6 Tahun 2014 tentang Hukum Jinayat. Pada prinsipnya qanun Hukum Jinayat adalah implementasi dari penerapan syari'at Islam di Aceh, sehingga pemerintah Aceh memandang perlu mengatur suatu ketentuan hukum tentang perbuatan pidana yang sesuai dengan syari'at Islam yaitu terhadap perbuatan pidana yang memiliki pengertian berbeda dengan ketentuan hukum pidana yang berlaku di Indonesia. Sedangkan bagi perbuatan pidana yang tidak diatur dalam qanun, tetap mengikuti Kitab UndangUndang Hukum Pidana (KUHP) dan Undang-Undang Pidana Khusus di Luar KUHP. Proses peradilan terhadap QanunNomor 6 Tahun 2014 tentang Hukum Jinayat dilaksanakan di Mahkamah Syar'iyah.

Pemberlakuan Qanun Nomor 6 Tahun 2014 tentang Hukum Jinayat (selanjutnya disebut Qanun Hukum Jinayat) turut mempengaruhi sistem peradilan pidana anak di Aceh, dimana sebelumnya perkara anak yang berkonflik dengan hukum diperiksa dan diadili oleh Pengadilan Negeri, namun saat ini dalam hal perkara anak yang berkonflik dengan hukum atas jarimah ${ }^{4}$ yang diatur dalam qanun tersebut menjadi kewenangan Mahkamah Syar'iyahuntuk memeriksa dan mengadilinya. Memeriksa dan mengadili perkara anak yang berkonflik dengan hukum merupakan hal yang baru bagi hakim Mahkamah Syar'iyah.

Pada kenyataannya di Kota Langsa, semua perkara-perkara anak yang berkonflik dengan hukum oleh kejaksaan masih diajukan kepada Pengadilan Negeri, walaupun anak yang berkonflik dengan hukum tersebut melakukan kejahatan yang juga diatur didalam qanun Hukum Jinayat. Keadaan ini terjadi terhadap perbuatan pidana pelecehan seksual. Secara nasional seorang anak yang berkonflik dengan hukum melakukan perbuatan pidana pelecehan seksual terhadap anak sebagai korbannya diancam dengan hukum pidana dalam Undang-Undang Nomor 35 Tahun 2014 tentang Perubahan Undang-Undang Nomor 23 Tahun 2002 tentang Perlindungan Anak.

3 Lihat Pasal 16 ayat (2) point a Undang-Undang Nomor 11 Tahun 2006 tentang Pemerintahan Aceh

4 Imam al-Mawardi menjelaskan bahwa: "jarimah adalah perbuatan-perbuatan yang dilarang oleh syara' yang diancam oleh Allah dengan hukum hadd atau ta'zir." Ibid., 
Sedangkan khusus untuk provinsi Aceh sanksi pidana perbuatan pelecehan seksual telah diatur secara kongkrit dalam qanun Hukum Jinayat. Sehingga dalam hal ini terjadi dualisme kewenangan mengadili perkara anak sebagai pelaku kejahatan pelecehan seksual di Kota Langsa-Aceh.

Pemilihan Kota Langsa sebagai lokasi penelitian berdasarkan data penelitian diantaranya wawancara yang dilakukan dengan Ibu Aklima Djuned selaku Panitera Muda Jinayat Terkait dengan adanya dualisme kewenangan mengadili di Aceh yaitu antara Mahkamah Syar'iyah dan Pengadilan Negeri Langsa khususnya perkara anak sebagai pelaku kejahatan, beliau menerangkan bahwa benar keadaan dualisme kewenangan mengadili terjadi dibeberapa kabuapaten di provinsi Aceh salah satunya Kota Langsa, apa yang telah menjadi kewenangan Mahkamah Syar'iyah, tetapi masih diperiksa dan diadili di Pengadilan Negeri, seperti kasus anak yangberkonflik dengan hukum, ditahun 2017 yang dilimpahkan ke Pengadilan Negeri Langsa, oleh Pengadilan Negeri Langsa ditolak kemudian dilimpahkan ke Mahkamah Syar'iyah, saat diminta perpanjangan penahanan kepada Mahkamah Syar'iyah Provinsi, saya bertanya mengapa ada penahanan oleh Pengadilan Negeri Langsa? Bukankah ini sudah menjadi kewenangan Mahkamah Syar'iyah? Namun proses perpanjangan dilakukan oleh Mahkamah Syar'iyah belum selesai, kami mendapat kabar bahwa Jaksa Penuntut Umum melakukan Banding Ke Pengadilan Tinggi di Banda Aceh, dan Putusan dari Pengadilan Tinggi memerintahkan Pengadilan Negeri Langsa untuk memeriksa dan mengadili perkara tersebut. ${ }^{5}$

Mengenai 2 (dua) ketentuan pidana yang digunakan mempengaruhi kewenangan mengadili di Aceh, lebih jauh lagi tentu ini berpengaruh pada sanksi pidana yang akan diputuskan karena qanun Hukum Jinayat memiliki ancaman pidana cambuk yang berbeda dengan Undang-Undang Nomor 35 Tahun 2014, tentunya ini berimplikasi pada disparitas keadilan yang diterima baik pelaku maupun korban perbuatan pidana, mengapa terjadi dualisme kewenangan mengadili perkara anak sebagai pelaku kejahatan pelecehan seksual di Kota Langsa-Aceh.

5 Wawancara dengan Iklima Djuned, Panitera Muda Jinayat Mahkamah Syar'iyah Banda Aceh pada tanggal 26 Juni 2018. 


\section{Rumusan Masalah}

Berdasarkan uraian tersebut di atas, beberapa permasalahan yang diangkat dalam penelitian ini adalah : 1. Bagaimana Dualisme Kewenangan Mengadili Perkara Anak Sebagai Pelaku Kejahatan Pelecehan Seksual di Kota Langsa-Aceh ? 2. Bagaimana Upaya Penanggulangan Dualisme Kewenangan Mengadili Perkara Anak Sebagai Pelaku Kejahatan Pelecehan Seksual di Kota Langsa-Aceh?

\section{Tujuan Penelitian}

Tujuan penelitian ini adalah untuk mengetahui Dualisme Kewenangan Mengadili Perkara Anak Sebagai Pelaku Kejahatan Pelecehan Seksual di Kota Langsa-Aceh dan untuk mengetahui Upaya Penanggulangan Dualisme Kewenangan Mengadili Perkara Anak Sebagai Pelaku Kejahatan Pelecehan Seksual di Kota Langsa-Aceh

\section{Metode Penelitian}

Dalam penelitian ini memberikan pengetahuan kepada penegak hukum dan masyarakat umum faktor yang menyebabkan terjadinya dualisme kewenangan mengadili perkara anak sebagai pelaku kejahatan pelecehan seksual di Kota LangsaAceh dan akibat yang ditimbulkan. Sehingga dapat menjadi dasar pertimbangan bagi penegak hukum untuk menanggulangi keadaan tersebut. Dalam penelitian ini digunakan jenis penelitian deskriptif analitis, dengan metode pendekatan yuridis empiris yaitu metode meneliti hak kewenangan mengadili perkara anak di Kota Langsa-Aceh dalam penerapan kenyataan hukumnya terjadi dualisme.

\section{B. PEMBAHASAN}

\section{Dualisme Kewenangan Mengadili Perkara Anak Sebagai Pelaku Kejahatan Pelecehan Seksual di Kota Langsa-Aceh}

Anak adalah aset bangsa dan pembangunan yang harus dilindungi untuk kepentingan ke depan yang terbaik bagi anak. Anak sebagai generasi penerus, pemegang nasib bangsa harus dipersiapkan untuk kepentingan bangsa ke depan yang terbaik. Merugikan kepentingan anak pada hakikatnya sama dengan merugikan kepentingan bangsa dan negara. Oleh sebab itu menjadi tanggungjawab negara untuk menentukan tindakan-tindakan tertentu dalam menangani anak yang terjerumus pada 
perbuatan pidana. Menimbang bahwa anak memiliki karakteristik yang unik dan berbeda dengan orang dewasa sehingga sistem peradilan pidana anak harus diatur secara khusus demi kepentingan terbaik bagi anak.

Pada tahun 1957 perhatian pemerintah terhadap kenakalan anak semakin membaik, terbukti dengan dikirimkannya beberapa ahli dari departemen Kepolisian, Kejaksaan, dan Kehakiman ke luar negeri untuk mempelajari hal-hal yang menyangkut juvenile delinquency, terutama mulai penyelidikannya sampai cara penyelesaian di muka pengadilan. Hasil yang disepakati adalah terbentuknya agreement secara lisan antara ketiga departemen tersebut untuk mengadakan perlakuan khusus bagi anak-anak yang melakukan tindak pidana. ${ }^{6}$

Perlindungan terhadap anak tentu melibatkan lembaga dan perangkat hukum yang memadai, untuk itu pada tanggal 3 Januari 1997 pemerintah mengesahkan UndangUndang Nomor 3 Tahun 1997 tentang Pengadilan Anak demi tercapainya cita hukum dalam hal perlindungan terhadap anak. kajian terhadap sistem peradilan pidana anak terus berkembang, dengan beberapa pertimbangan seperti: batas usia pertanggungjawaban pidana anak, metode penyelesaian pidana anak yang menekankan pada penghindaran pemidanaan penjara, beberapa instansi yang mendukung dalam hal pemulihan psikologis anak, dan lainnya, akhirnya pada tanggal 3 Juli 2012, lahir Undang-Undang Nomor 11 Tahun 2012 Tentang Sistem Peradilan Pidana Anak (UUSPPA) dengan konsep keadilan restoratif.

Fenomena kejahatan pelecehan seksual di Indonesia terus meningkat, pelakunya bukan hanya orang dewasa, tetapi juga anak. Anak yang melakukan kejahatan pelecehan seksual terhadap anak diancam pidana dalam Undang-Undang 35 Tahun 2014 tentang Perubahan Undang-Undang Nomor 23 Tahun 2002 tentang Perlindungan Anak (UUPA). Kemudian pelaksanaan peradilan pidana anak menjadi kewenangan Pengadilan Negeri. Berbeda dengan di Aceh dimana Mahkamah syar'iyah ${ }^{7}$ memiliki

6 Wigiati Soetedjo dan Melani, Hukum Pidana Anak, Jakarta: Refika Aditama, 2013, hlm. 3

7 Mahkamah syar'iyahhanya dikenal di provinsi Aceh, sebagai lembaga pengadilan yang berwenang memeriksa, mengadili dan menyelesaikan persoalan-persoalan yang diajukan oleh umat Islam kepadanya. Di daerah lain sebutan Mahkamah Syar'iyah masih dikenal dengan nama Pengadilan Agama sebagai pengadilan yang berwenang, memeriksa, mengadili dan memutuskan perkara-perkara antara orang yang beragama Islam sesuai dengan kewenangan absolute dan relatifnya masing-masing. Qanun Nomor 10 Tahun 2002 tentang Peradilan Syari'at Islam mengatur tentang kewenangan Mahkamah Syar'iyah yaitu memeriksa, memutus dan menyelesaikan perkara pada tingkat pertama dalam bidang al-ahwal al-shakhsyiah, muamalah, dan 
kewenangan absolut melaksanakan peradilan pidana anak terhadap perkara kejahatan seksual yang dilakukan oleh anak disebabkan kejahatan pelecehan seksual tersebut termasuk jarimah yang dilarang dalam qanun Hukum Jinayat.

Qanun Hukum Jinayat terdiri dari 10 (sepuluh) Bab dan 75 (tujuh puluh lima) Pasal. Ada 10 (sepuluh) perbuatan pidana yang diatur dalam qanun Hukum Jinayat, yaitu:
a. Khamar;
b. Maisir;
c. Khalwat;
d. Ikhtilat;
e. Zina;
f. Pelecehan Seksual;
g. Pemerkosaan;
h. Qadzaf;
i. Liwath; dan
j. Musahaqah.

Dualisme kewenangan mengadili terdapat dalam perkara tindak pidana pelecehan seksual terhadap anak. Dimana UUPA dalam Pasal 76D menyebutkan: "setiap orang dilarang melakukan kekerasan atau ancaman kekerasan memaksa anak melakukan persetubuhan dengannya atau dengan orang lain”. Selanjutnya Pasal 76E menyebutkan: "setiap orang dilarang melakukan kekerasan atau ancaman kekerasan, memaksa, melakukan tipu muslihat, melakukan serangkaian kebohongan, atau membujuk anak untuk melakukan atau membiarkan dilakukan perbuatan cabul”.

Sanksi pidana terhadap kejahatan seksual tersebut yaitu Pasal 76D tindak pidana pemerkosaan diatur dalam Pasal 81 yang berbunyi:

1) Setiap orang yang melanggar ketentuan sebagaimana dimaksud dalam Pasal 76D dipidana dengan pidana penjara paling singkat 5 (lima) tahun dan paling lama 15 (lima belas) tahun dan denda paling banyak Rp5.000.000.000,00 (lima miliar rupiah).

\footnotetext{
jinayah. Zulkarnain Lubis dan H. Bakti Ritonga, , Dasar-dasar Hukum Acara Jinayah, Jakarta:
} Prenamedia Group, 2016, hlm 1. 
2) Ketentuan pidana sebagaimana dimaksud pada ayat (1) berlaku pula bagi Setiap Orang yang dengan sengaja melakukan tipu muslihat, serangkaian kebohongan, atau membujuk Anak melakukan persetubuhan dengannya atau dengan orang lain.

3) Dalam hal tindak pidana sebagaimana dimaksud pada ayat (1) dilakukan oleh Orang Tua, Wali, pengasuh Anak, pendidik, atau tenaga kependidikan, maka pidananya ditambah 1/3 (sepertiga) dari ancaman pidana sebagaimana dimaksud pada ayat (1).

Kemudian sanksi pidana terhadap Pasal 76E tindak pidana pencabulan diatur dalam Pasal 82 yang berbunyi:

1) Setiap orang yang melanggar ketentuan sebagaimana dimaksud dalam Pasal $76 \mathrm{E}$ dipidana dengan pidana penjara paling singkat 5 (lima) tahun dan paling lama 15 (lima belas) tahun dan denda paling banyak Rp5.000.000.000,00 (lima miliar rupiah).

2) Dalam hal tindak pidana sebagaimana dimaksud pada ayat (1) dilakukan oleh Orang Tua, Wali, pengasuh Anak, pendidik, atau tenaga kependidikan, maka pidananya ditambah $1 / 3$ (sepertiga) dari ancaman pidana sebagaimana dimaksud pada ayat (1)

Sementara dalam qanun Hukum Jinayat, Pasal 48 menyebutkan:

Setiap orang yang dengan sengaja melakukan jarimah pemerkosaan diancam dengan 'uqubat Ta'zir cambuk paling sedikit 125 (seratus dua puluh lima) kali, paling banyak 175 (seratus tujuh puluh lima) kali atau denda paling sedikit 1.250 (seribu dua ratus lima puluh) gram emas murni, palin banyak 1.750 (seribu tujuh ratus lima puluh) gram emas murni, atau penjara paling singkat 125 (seratus dua puluh lima) bulan, paling lama 175 (seratus tujuh puluh lima) bulan.

Pasal 49 menyebutkan:

Setiap orang yang dengan sengaja melakukan jarimah pemerkosaan terhadap orang yang memiliki hubungan mahram dengannya, diancam dengan 'uqubat Ta'zir cambuk paling sedikit 150 (seratus lima puluh) kali, paling banyak 200 (dua ratus) kali atau denda paling sedikit 1.500 (seribu lima ratus) gram emas murni, paling banyak 
2.000 (dua ribu), gram emas murni atau penjara paling singkat 150 (seratus lima puluh) bulan, paling lama 200 (dua ratus) bulan.

Pasal 50 menyebutkan:

Setiap orang yang dengan sengaja melakukan jarimah pemerkosaan sebagaimana dimaksud dalam Pasal 48 terhadap anak-diancam dengan 'uqubat Ta'zir cambuk paling sedikit 150 (seratus lima puluh) kali, paling banyak 200 (dua ratus) kali atau denda paling sedikit 1.500 (seribu lima ratus) gram emas murni, paling banyak 2.000 (dua ribu) gram emas murni atau penjara paling singkat 150 (seratus lima puluh) bulan, paling lama 200 (dua ratus) bulan.

Pasal 66 mengatur mengenai jarimah dan 'uqubat bagi anak-anak, yaitu:

Apabila anak yang belum mencapai umur 18 (delapan belas) tahun melakukan atau diduga melakukan Jarimah, maka terhadap Anak tersebut dilakukan pemeriksaan berpedoman kepada peraturan perundang-undangan mengenai peradilan pidana anak.

Pada kenyataannya di Kota Langsa saat ini, instansi Kejaksaan masih saja mengajukan perkara anak sebagai pelaku kejahatan pelecehan seksual kepada Pengadilan Negeri dengan menggunakan ketentuan dalam UUPA, padahal ketentuan pelecehan seksual telah diatur dalam qanun Hukum Jinayat dan dalam hal ini kewenangan mengadili ada pada Mahkamah syar'iyah.

Zakiruddin menjelaskan bahwa dalam menangani perkara anak sebagai pelaku kejahatan Mahkamah Syar'iyah berpedoman pada UUSPPA dan qanun Nomor 7 Tahun 2013 tentang Hukum Acara Jinayah. Seharusnya jika kejaksaan paham dengan Kompetensi kewenangan mengadili dari Mahkamah Syar'iyah, maka tidak akan ada lagi perkara anak yang berkonflik dengan hukum diajukan ke Pengadilan Negeri. Karena didalam Pasal 7 qanunHukum Jinayat disebutkan bahwa dalam hal ada perbuatan Jarimah sebagaimana diatur dalam qanun ini dan diatur juga dalam Kitab Undang-Undang Hukum Pidana (KUHP) atau ketentuan pidana di luar KUHP, yang berlaku adalah aturan Jarimah dalam qanun ini. ${ }^{8}$

Hakim Anak Pengadilan Negeri Langsa, Kurniawan saat ditemui membenarkan bahwa sampai saat ini Pengadilan Negeri Langsa masih memeriksa dan mengadili perkara anak sebagai pelaku kejahatan pelecehan seksual dikarenakan Jaksa Penuntut Umum (JPU) dalam surat dakwaannya menggunakan UUPA bukan qanun Hukum

8 Wawancara dengan Zakiruddin, Hakim Ketua Mahkamah Syar'iyahLangsa pada tanggal 19 Juni 2018. 
Jinayat. Pihaknya sudah menjelaskan mengenai asas asas lex spesialis derogate lex generalis kepada JPU, bahkan Pengadilan Negeri Langsa pernah menolak perkara tersebut, tetapi JPU banding, dan putusan dari Pengadilan Tinggi memerintahkan Pengadilan Negeri Langsa untuk memeriksa dan mengadili perkara tersebut. ${ }^{9}$

Sementara keterangan yang diberikan oleh Reza Rachim bahwa alas an penggunaan UUPA dalam dakwaannya karena menurutnya UUPA memiliki tingkatan hirarki yang lebih tinggi dibandingkan qanun Hukum Jinayat, disamping itu sarana dan prasarana bagi sistem peradilan pidana anak lebih memadai di Pengadilan Negeri Langsa dibandingkan dengan Mahkamah Syar'iyah, termasuk amanat UUSPPA dalam Pasal 43 ayat (2) bahwa syarat untuk dapat ditetapkan sebagai Hakim dalam melaksanakan peradilan anak salah satu yang paling mendasar adalah telah mengikuti pelatihan teknis tentang peradilan Anak, dan hakim pada Mahkamah Syar'iyahbelum ada yang memenuhi syarat ini. Reza melanjutkan adanya kekhawatiran terhadap penjatuhan sanksi pidana jika menggunakan qanun Hukum Jinayat, yaitu memungkinkan adanya hukuman cambuk bagi anak, sedangkan UUSPPA sebagai pedoman dalam melaksanakan peradilan anak menegaskan bahwa identitas anak harus dilindungi. Sebagai penegak hukum jaksa juga memandang perlu untuk melakukan perlindungan terhadap anak yang berkonflik dengan hukum ${ }^{10}$

Qanun adalah peraturan perundang-undangan sejenis peraturan daerah provinsi yang mengatur penyelenggaraan pemerintahan kehidupan masyarakat Aceh. Kenyataannya qanun tidaklah sama persis dengan peraturan daerah. Walaupun dari segi qanun disebutkan sebagai peraturan daerah, tetapi dia diberi kekuatan khusus yaitu merupakan peraturan pelaksanaan langsung untuk undang-undang dalam urusan otonomi khusus. Dengan kata lain qanun merupakan pelaksanaan yang hirarkis berada langsung dibawah Undang-Undang Nomor 11 Tahun 2006 tentang Pemerintah Aceh, sehingga Undang-Undang Nomor 11 Tahun 2006 dapat mengenyampingkan peraturan perundang-undangan lainnya dengan mengikuti asas lex spesialis derogate lex generalis. Ada beberapa prinsip yang harus diperhatikan dalam asas lex spesialis derogate lex generalis, yaitu: ${ }^{11}$

9 Wawancara dengan Kurniawan, Hakim Anak Pengadilan Negeri Langsa pada tanggal 20 Juni 2018.

10 Wawancara dengan Reza Rahim, Jaksa Pidana Umum Langsa pada tanggal 4 Juli 2018.

11 Bagir Manan, Hukum Positif Indonesia, Jakarta: Penerbit UII Press, 2004, hlm. 56. 
a. Ketentuan yang didapati dalam aturan hukum umum tetap berlaku kecuali yang diatur khusus dalam aturan hukum khusus tersebut.

Dalam kaitannya pengaturan hukum pidana di Aceh, pengaturan hukum pidana umum dapat dikesampingkan apabila telah diatur secara khusus dalam qanun Hukum Jinayat.

b. Ketentuan-ketentuan lex spesialis harus sederajat dengan ketentuan-ketentuan lex generalis (undang-undang dengan undang-undang).

Dalam kaitannya pengaturan hukum pidana di Aceh, qanun adalah peraturan pelaksana langsung dari Undang-Undang Nomor 11 Tahun 2006 tentang Pemerintah Aceh, sehingga Undang-Undang Nomor 11 Tahun 2006 menjadi sederajat dengan KUHP dan Undang-Undang Pidana Khusus di Luar KUHP

c. Ketentuan-ketentuan lex spesialis berada dalam lingkungan hukum yang sama dengan lex generalis.

Dalam kaitannya pengaturan hukum pidana di Aceh, qanun Hukum Jinayat memiliki lingkungan hukum yang sama dengan KUHP dan Undang-Undang Pidana Khusus di Luar KUHP, yaitu sama-sama mengatur tentang perbuatan pidana.

Berdasarkan uraian diatas, seharusnya penggunaan asas lex spesialis derogate lex generalis dapat diterapkan juga terhadap perkara anak sebagai pelaku kejahatan pelecehan seksual, yaitu Jaksa Penuntut Umum menggunakan ketentuan yang ada dalam qanun Hukum Jinayat, sehingga tidak terjadi dualisme kewenangan mengadili. Sebagaimana pelaksanaan peradilan anak oleh Mahkamah Syar'iyah Kabupaten lainnya di Provinsi Aceh.

\section{Upaya Penanggulangan Dualisme Kewenangan Mengadili Perkara Anak} Sebagai Pelaku Kejahatan Pelecehan Seksual di Kota Langsa-Aceh

Dualisme kewenangan mengadili yang terjadi di Kota Langsa-Aceh, tidak dapat dipandang sederhana, mengingat kemungkinan terjadinya perbedaan yang mendasar dalam penerapan sanksi pidana dari dua peradilan yaitu Pengadilan Negeri dan Mahkamah Syar'iyah. Hakim Kurniawan ${ }^{12}$ menerangkan bahwa dalam pelaksanaan peradilan pidana anak Pengadilan Negeri berpedoman pada UUSPPA, PP Nomor 65 Juni 2018.

12 Wawancara dengan Kurniawan, Hakim Anak Pengadilan Negeri Langsa pada tanggal 20 
Tahun 2015 tentang Pedoman Pelaksanaan Diversi Dan Penanganan Anak Yang Belum Berumur 12 (dua belas) Tahun, Perma Nomor 4 tahun 2014 tentang Pedoman Pelaksanaan Diversi dalam Sistem Peradilan Pidana Anak, Kemensos Nomor 85/HUK/2017 tentang Lembaga Penyelenggaraan Kesejahteraan Sosial sebagai Pelaksana Rehabilitasi Sosial Anak Yang Berhadapan Dengan Hukum.

Berdasarkan hak tersebut maka jenis-jenis pidana yang diterapkan pada anak yang berkonflik dengan hukum adalah sesuai dengan Pasal 71 UUSPPA, yaitu:

(1) Pidana pokok bagi Anak terdiri atas:

a. pidana peringatan;

b. pidana dengan syarat:

1) pembinaan di luar lembaga;

2) pelayanan masyarakat; atau

3) pengawasan.

c. pelatihan kerja;

d. pembinaan dalam lembaga; dan

e. penjara.

(2) Pidana tambahan terdiri atas:

a. perampasan keuntungan yang diperoleh dari tindak pidana; atau

b. pemenuhan kewajiban adat.

Namun jika pelaksanaan peradilan pidana anak dilaksanakan oleh Mahkamah Syar'iyah, suatu keniscayaan penerapan pidana cambuk dijatuhkan terhadap anak yang berkonflik dengan hukum. Seperti contoh putusan Mahkamah Syar'iyah Aceh Nomor 01/JN.Anak/2017/MS-Aceh terhadap banding yang diajukan oleh JPU Tapaktuan, Mahkamah Syar'iyah Aceh dalam putusannya menyatakan menguatkan putusan Mahkamah Syar'iyahTapaktuan Nomor 0001/Anak/2017/MS.Ttn, menyatakan anak pelaku terbukti secara sah dan meyakinkan bersalah melakukan jarimah pelecehan seksual terhadap anak, menjatuhkan pidana 'uqubat kepada anak pelaku dengan 'uqubat cambuk sebanyak 5 (lima) kali cambuk. 
Keadaan tersebut jelas akan menimbulkan disparitas ${ }^{13}$ pidana dan disparitas ini berakibat fatal, terpidana yang setelah memperbandingkan pidana kemudian merasa menjadi korban "the judicial caprice" akan menjadi pidana yang tidak menghargai hukum, padahal penghargaan terhadap hukum tersebut merupakan salah satu target dalam tujuan pemidanaan.

Diketahui dari uraian sebelumnya bahwa ada beberapa alasan dari kejaksaan Kota Langsa tidak berkenan mengajukan perkara anak yang berkonflik dengan hukum kepada Mahkamah Syar'iyah, misalnya menyangkut sarana dan prasarana yang belum memadai sebagaimana yang diamanatkan dalam ketentuan SPPA. Mahkamah Syar'iyah Aceh dalam ini harus membuat langkah-langkah penanggulangan yang cepat demi terjaminnya usaha perlindungan terhadap anak.

Iklima Djuned mengatakan bahwa Mahkamah Syar'iyahAcehmengakui jika masih benyak terdapat kekurangan-kekurangan dari segi sarana dan prasarana yang mendukung sistem peradilan pidana anak, tapi kita terus berusaha menanggulanginya dengan mengusulkan kepada Mahkamah Agung untuk pengadaan beberapa sarana dan prasarana tersebut, mengusulkan untuk mengikutsertakan Hakim Mahkamah Syar'iyah dalam pelatihan sertifikasi hakim anak. ${ }^{14}$

Demikian juga terhadap penerapan sanksi pidana terhadap anak, Mahkamah Syar'iyah harus berpedoman terhadap Pasal 71 UUSPPA, ada beberapa pemilihan sanksi pidana selain pidana berupa penjara atau cambuk. Sistem peradilan pidana anak mengalami pembaharuan, salah satunya adalah pengaturan tentang hukum pidana dalam perspektif Keadilan Restoratif ${ }^{15}$ yaitu: penyelesaian perkara tindak pidana dengan melibatkan pelaku, korban, keluarga pelaku/korban, dan pihak lain yang terkait untuk bersama-sama mencari penyelesaian yang adil dengan menekankan pemulihan kembali pada keadaan semula, dan bukan pembalasan. Bentuk pidana terhadap anak yang berkonflik dengan hukum yang ditawarkan misalnya pembinaan di dalam dan di luar Lembaga, pelayanan masyarakat maupun pelatihan kerja.

13 Disparitas (disparity of sentencing) yaitu penerapan pidana yang tidak sama terhadap tindak pidana yang sama (same offence), Muladi dan Barda Nawawi Arief, Teori-Teori dan Kebijakan Pidana. Bandung: Alumni, 2010, hlm. 52.

14 Wawancara dengan Iklima Djuned, Panitera Muda Jinayat Mahkamah Syar'iyah Banda Aceh pada tanggal 26 Juni 2018.

15 Lihat Pasal 1 angka 6 Undang-Undang Nomor 11 Tahun 2012 tentang Sistem Peradilan Pidana Anak. 
Tujuan utama dari bentuk pidana tersebut adalah menghindari anak dari pemenjaraan yang berdampak buruk bagi anak, memperbaiki kondisi-kondisi sosial tertentu, namun secara tidak langsung mempunyai pengaruh preventif terhadap kejahatan. Oleh karena itu penerapan hukuman cambuk bagi anak memerlukan kajian yang lebih mendalam agar tidak menciderai prinsip-prinsp perlindungan terhadap anak sesuai Fundamental Rights and Freedoms Of Children adalah Hak asasi anak dan kebebasan anak telah diakui secara internasional melalui Konvensi Hak Anak (United Nations Convention on the Rights of the Child). KHA merupakan instrumen yang berisi tentang prinsip-prinsip universal dan ketentuan hukum mengenai hak-hak anak berdasarkan sebuah perjanjian internasional mengenai hak asasi manusia yang memasukkan unsur-unsur hak sipil, hak politik, hak ekonomi, hak sosial dan hak budaya. Terdapat 4 prinsip umum dari KHA yaitu : (1) Asas Nondiskriminasi; (2) Asas Kepentingan Terbaik Bagi Anak (best interest of the child); (3) Asas Hak Hidup, Kelangsungan hidup, dan perkembangan (the rights to life, survival and development); (4) Asas Penghargaan Atas Pendapat Anak (respect for the views of the child).

\section{SIMPULAN}

1. Terjadi dualisme kewenangan mengadili perkara anak sebagai pelaku kejahatan pelecehan seksual di Kota Langsa dikarenakan ada dua ketentuan peraturan perundang-undangan yang digunakan untuk penegakan hukum perkara tersebut yaitu Undang-Undang Nomor 35 Tahun 2014 tentang Perubahan Undang-Undang Nomor 23 Tahun 2002 tentang Perlindungan Anak (UUPA) dimana kewenangan mengadili ada pada Pengadilan Negeri sedangkan Qanun Nomor 6 Tahun 2014 tentang Hukum Jinayat, kewenangan mengadili ada pada Mahkamah Syar'iyah.

2. Faktor penyebab kejaksaan penggunaan UUPA dalam dakwaannya karena menurutnya sarana dan prasarana bagi sistem peradilan pidana anak lebih memadai di Pengadilan Negeri Langsa dibandingkan dengan Mahkamah Syar'iyah, belum ada hakim yang bersertifikasi hakim anak pada Mahkamah Syar'iyah, adanya kekhawatiran terhadap penjatuhan sanksi pidana cambuk terhadap anak jika menggunakan qanun Hukum Jinayat. Ketiga, penanggulangan yang harus dilakukan oleh Mahkamah Syar'iyah adalah melengkapi sarana dan prasarana sistem peradilan anak yang memadai dan menjadikan jenis-jenis 
pemidanaan yang ada dalam UUSPPA sebagai pedoman sehingga tidak menimbulkan disparitas pidana.

\section{DAFTAR PUSTAKA}

\section{Buku:}

Lubis, Zulkarnain dan H. Ritonga Bakti. 2016. Dasar-dasar Hukum Acara Jinayah. Jakarta: Prenamedia Group

Manan, Bagir. 2004. Hukum Positif Indonesia. Jakarta: Penerbit UII Press

Muladi dan Barda Nawawi Arief. 2010. Teori-teori dan Kebijakan Pidana. Bandung: Alumni

R, Babbie. 1977. The Practice of Social Research Practice. Belmont: Wadworth

Soetedjo,Wigiati dan Melani. 2013. Hukum Pidana Anak. Jakarta: Refika Aditama

\section{Peraturan Perundang-undangan:}

Undang-Undang Nomor 11 Tahun 2006 tentang Pemerintahan Aceh

Undang-Undang Nomor 11 Tahun 2012 tentang Sistem Peradilan Pidana Anak

Undang-Undang Nomor 35 Tahun 2014 tentang Perubahan Undang-Undang Nomor 23 Tahun 2002 tentang Perlindungan Anak

Qanun Nomor 6 Tahun 2014 tentang Hukum Jinayat

Memorandum of Understanding between the Government of the Republic of Indonesia and the Free Aceh Movement 